\title{
OBTAINING OF COUMARONE-INDENE RESINS BASED ON LIGHT FRACTION OF COAL TAR 2. COUMARONE-INDENE RESINS WITH EPOXY GROUPS
}

\author{
Michael Bratychak ${ }^{1, *}$, O resta Ripak ${ }^{1}$, Jacek Namiesnik ${ }^{2}$, Olena Shyshchak ${ }^{1}$, \\ Olena Astakhova ${ }^{1}$
}

https://doi.org/10.23939/chcht12.01.093

\begin{abstract}
Coumarone-indene resins with epoxy groups (CIRE) have been obtained using light fraction of coal tar or fraction with the distillation range of $423-463 \mathrm{~K}$ based on it. Styrene and glycidyl methacrylate were used as modifiers. CIRE were synthesized via radical cooligomerization using monoperoxide derivative of dioxyphenylpropane diglycidyl ether (PO) as an initiator. Thermal stability of PO has been studied. The effect of initiator amount, reaction temperature and time on the yield and softening temperature of CIRE has been determined. The structure of the synthesized CIRE was confirmed by IR and ${ }^{1} \mathrm{H}$ NMR spectroscopy.
\end{abstract}

Keywords: coumarone-indene resin, coal tar, glycidyl methacrylate, styrene, peroxide, thermolysis, infrared spectroscopy, ${ }^{1} \mathrm{H}$ NMR spectroscopy.

\section{Introduction}

Nowadays the polymeric (oligomeric) compounds are independently used for the production of various goods and as additives for the creation of composites [1, 2]. At the same time the increased requirements for the polymeric materials demand the creation of polymers (oligomers) with definite operational characteristics. This may be achieved via combining different by nature monomers which participate in the production of polymeric compound or via modifying the finished polymer by various additives [1].

Last decade a series of researches has been carried out in Lviv Polytechnic National University regarding the usage of industrial wastes for the production of new polymeric compounds [3-12]. These wastes contain

\footnotetext{
${ }^{1}$ Lviv Polytechnic National University

12, S.Bandery St., 79013 Lviv, Ukraine

${ }^{2}$ Gdansk University of Technology,

11/12 G. Narutowicza St., 80233 Gdansk, Poland

mbratychak@gmail.com

(C) Bratychak M., Ripak O., Namiesnik J., Shyshchak O., Astakhova O., 2018
}

different by nature monomers capable of creating new polymeric compounds under certain conditions.

For instance, the so called C9 fraction is obtained after rectification of the product obtained during hydrocarbons pyrolysis to ethylene $[3,4]$. The $\mathrm{C} 9$ fraction contains $40-70 \%$ of unsaturated compounds; it is successfully used for the production of petroleum resins [3-12]. The introduction of functional groups, namely epoxy [5], carboxy [9], hydroxy [14] and other groups [12] into the resin structure allows to use the resins as additives when producing protective coatings [13], bitumen-polymeric mixtures [15] and different materials [16].

Indene-coumarone fraction (ICF) is produced from coal tar which is a by-product of coal coking [17]. It contains components capable of polymerization, and hence, may be used for the production of coumaroneindene resins (CIR) [17]. CIR obtained via ionic polymerization are used as polymeric components while creating bitumen-polymeric mixtures [18] but they have limited application due to the absence of functional groups in their structure.

Another by-product of a coking process is a light fraction of coal tar (LFCT). Similar to ICF it contains coumarone, indene, styrene and other unsaturated products and also may be used for the production of CIR. Previously we described CIR with free carboxy groups obtained from LFCT via radical polymerization with addition of styrene and methacrylic acid [19]. 2,2-Azobis(2-methylpropionitrile) was used as an initiator, the process temperature was $353 \mathrm{~K}$, time $6 \mathrm{~h}$. The content of carboxy groups in the synthesized CIR was $13.8 \%$, the softening temperature $391-392 \mathrm{~K}$ and molecular weight $950 \mathrm{~g} / \mathrm{mol}$. The resins yield was $9.7 \%$ relative to the initial mixture and $68 \%$ - relative to the components capable of polymerization. When using chromatography it was established that only methacrylic acid completely undergoes a copolymerization reaction resulting in CIR formation. Styrene conversion was $40.8 \%$, coumarone $-30.6 \%$, indene $-45.2 \%$ [19]. 
The purpose of the present work is to obtain CIR with epoxy groups from LFCT. Glycidyl methacrylate is an additional monomer. We propose to use monoperoxide derivative of dioxyphenylpropane diglycidyl ether (PO) as an initiator for the synthesis. PO formula is:<smiles>[R]CC(O)COC(C)(C)C</smiles>

$\mathrm{R}=-\mathrm{OC}_{6} \mathrm{H}_{4} \mathrm{C}\left(\mathrm{CH}_{3}\right)_{2} \mathrm{C}_{6} \mathrm{H}_{4} \mathrm{O}-$

Free epoxy group of $\mathrm{PO}$ is introduced into the synthesized compound and allows to obtain oligomeric products with epoxy groups. Apart from free epoxy group, $\mathrm{PO}$ contains labile $-\mathrm{O}-\mathrm{O}-$ bond. It means an additional source of free radicals stimulating the polymerization of monomers.

\section{Experimental}

\subsection{M aterials}

The raw materials for CIRE synthesis were light fraction of coal tar (LFCT), produced at JSC "Zaporizhkoks" (Ukraine), and indene-coumarone fraction (ICF) with the distillation range of $423-463 \mathrm{~K}$ based on it. The content of the components is described in [19].

To increase the CIR yield we used styrene. It was dried before the experiments with solid alkali and then purified by distillation at $323 \mathrm{~K}$ under residue pressure of 300-400 Pa. Its characteristics: refractive index $n_{D}^{20}=$ $=1.5471$ (literature value $n_{D}^{20}=1.5468$ ); density $d_{4}^{20}=0.650$ (literature value $d_{4}^{20}=0.9059$ ) [20]. Glycidyl methacrylate (GMA) was a monomer with $d_{4}^{20}=1.042, n_{D}^{20}=1.449$ purchased from Aldrich. Monoperoxide derivative of dioxyphenylpropane diglycidyl ether was synthesized according to the procedure described in [21]. Its characteristics: molecular weight $420 \mathrm{~g} / \mathrm{mol}$, epoxy number $10 \%$, active oxygen content $2.7 \%$. Toluene was purchased from Aldrich. The petroleum ether was a fraction with a boiling range of $313-343 \mathrm{~K}, d_{4}^{20}=0.650$.

\subsection{Analytical Determination}

The number-average molecular weight $\left(M_{n}\right)$ of the synthesized CIR was determined using cryoscopy in dioxane. Epoxy number (e.n.) was determined according to the procedure described in [22]. The softening temperature of CIR was determined using a ring-and-ball method [23].

\subsection{Thermal Analyses}

Thermal studies were carried out to determine the decomposition temperature of $\mathrm{PO}$ relative to the peroxy group using Q-1500 D derivatograph (F.PaulikJ.Paulik-L.Erdey). The samples were analyzed under dynamic mode at the heating rate of $2.5 \mathrm{~K} / \mathrm{min}$ in air atmosphere. The sample was heated to the temperature of $523 \mathrm{~K}$; its weight was $300 \mathrm{mg}$. The reference substance was alumina. TG sensitivity was $100 \mathrm{mg}$, DTA sensitivity $100 \mu \mathrm{V}$, DTG sensitivity $500 \mu \mathrm{V}$.

\subsection{Spectral M easurements}

IR spectra of CIRE were recorded using "Specord80 " spectrophotometer (Zeiss, Germany) with the relevant absorbance range of $4000-400 \mathrm{~cm}^{-1}$. The samples were dissolved in acetone and obtained films were applied over the plate with $\mathrm{KBr}$ (layer thickness was $0.03 \mathrm{~mm}$ ).

$\mathrm{H}$ NMR spectra were recorded at $353 \mathrm{~K}$ using a Varian Mercury Vx Spectrometer operating at Larmor frequencies of $400 \mathrm{MHz}$. The spectral width was $6402.0 \mathrm{~Hz}$, acquisition time $1.998 \mathrm{~s}$ and the number of recorded scans 64 .

\subsection{Synthesis Procedure}

LFCT or ICF cooligomerization was carried out in metal ampoules by the capacity of $100 \mathrm{ml}$. The ampoules were loaded with the corresponding mixture, blown with an inert gas, closed and placed into a thermostat. After finishing the process the ampoules were cooled to room temperature and the matter was precipitated using petroleum ether. The precipitated product was dried in a vacuum oven at $313 \mathrm{~K}$ till the weight became constant. The yields relative to the initial reaction mixture $\left(X_{1}\right)$ and main resin-formed components (styrene, indene, coumarone, GMA) $\left(X_{2}\right)$ were calculated according to the formulae (1) and (2), respectively:

$$
\begin{gathered}
X_{1}=\frac{m_{r}}{m_{i n}} \cdot 100 \% \\
X_{2}=\frac{m_{r}}{m_{s t}+m_{i n}+m_{c m}+m_{G M A}} \cdot 100 \%
\end{gathered}
$$

where $m_{r}$ - weight of the resulted resin, g; $m_{i n}$ - weight of the initial reaction mixture, g; $m_{s t}, m_{i n}, m_{c m}, m_{M A A}-$ weights of styrene, indene, coumarone and GMA, respectively.

\section{Results and Discussion}

\subsection{PO Thermal Stability}

In order to use $\mathrm{PO}$ as the initiator, it is necessary to know about its thermal stability, i.e. the temperature under which the -O-O- bonds are decomposed and free radicals are formed. The results of thermal studies are represented in Fig. 1. 
Table 1

Kinetic parameters of PO thermal stability

\begin{tabular}{|l|c|}
\hline \multicolumn{1}{|c|}{ Parameters } & Values \\
\hline Initial temperature of weight loss, $\mathrm{K}$ & 393 \\
\hline Finishing temperature of weight loss, $\mathrm{K}$ & 475 \\
\hline Maximum exoeffect, $\mathrm{K}$ & 440 \\
\hline Reaction order & 1.4 \\
\hline$Z, \mathrm{~s}^{-1}$ & $1.33 \cdot 10^{18}$ \\
\hline$E, \mathrm{~kJ} / \mathrm{mol}$ & 168 \\
\hline$k \cdot 10^{2}, \mathrm{~s}^{-1}$ & 0.89 \\
\hline
\end{tabular}

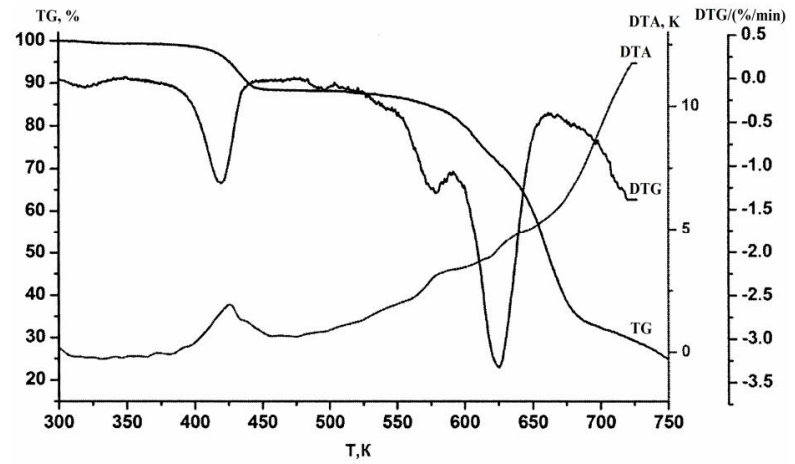

Fig. 1. TG, DTG and DTA curves for PO

Thermolysis kinetic parameters were calculated at the stage of peroxy groups using Mathcad 2011 Professional software on the basis of the modified kinetic equation and least-squares method according to Eq. (3):

$$
\ln \frac{d w}{w_{k} \cdot d T}=\ln \frac{Z}{q}
$$

where $w$ - PO weight loss at definite temperature, mg; $w_{k}$ - total weight loss of PO at the definite stage, $\mathrm{mg} ; Z-$ preexponential factor, $\mathrm{s}^{-1} ; E$ - activation energy, $\mathrm{kJ} / \mathrm{mol}$; $R$ - universal gas constant $(R=8.314 \mathrm{~J} / \mathrm{mol} \cdot \mathrm{K}) ; q-$ heating rate of $\mathrm{PO}$, grad $/ \mathrm{min}$.

The results obtained according to Eq. (3) are represented in Table 1.

The results presented in Fig. 1 and Table 1 show that the -O-O- bond in PO is decomposed already at $393 \mathrm{~K}$. Moreover, the most intense decomposition with the formation of free radicals is observed at $440 \mathrm{~K}$. On the basis of obtained results and literature data [24] the formation of free radicals and chemistry of PO decomposition may be represented by the following equations:<smiles>[3H]CC(O)COC(C)(C)C</smiles><smiles>CC(C)(C)OCC(O)C[Te]CC1CO1</smiles>

$\left(\mathrm{R}_{1}\right)$

$\left(\mathrm{R}_{2}\right)$

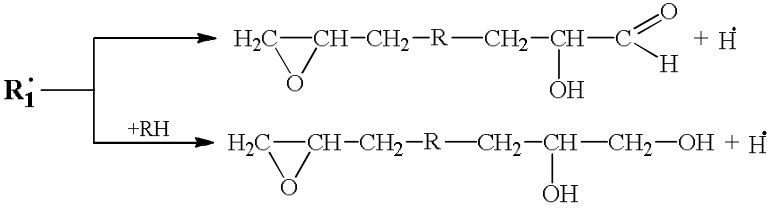

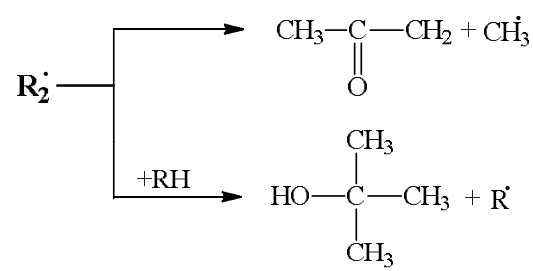

$$
\begin{aligned}
& \mathrm{CH}_{3}+\mathrm{H} \longrightarrow \mathrm{CH}_{4} \\
& \mathrm{CH}_{3}+\mathrm{R} \longrightarrow \mathrm{R}-\mathrm{CH}_{3} \\
& \mathrm{R}^{\bullet}+\mathrm{R}^{*} \longrightarrow \mathrm{R}-\mathrm{R}
\end{aligned}
$$

So, the PO weight loss at low temperatures occurs due to the transformation of radicals and formation of volatile products such as methane, acetone and tert-butyl alcohol. The formation of free radicals is observed at $393 \mathrm{~K}$.

\subsection{Coumarone-Indene Resins with Epoxy Groups (CIRE)}

LFCT and ICF are the initial raw materials for CIRE production. To increase the resins yield we additionally used styrene. Glycidyl methacrylate (GMA) was used as a monomer to impart functionality to CIRE, i.e. to introduce epoxy groups into CIRE structure. $\mathrm{PO}$ as a $50 \%$ solution was used as an initiator for the monomers which are contained in LFCT or ICF, styrene and GMA.

To develop the procedure for CIRE synthesis in the presence of PO it was necessary to study the effect of initiator amount, the reaction temperature and time on the CIRE yield. The investigated mixture consists of (mass parts): 45.2 of LFCT, 5.45 of styrene and 4.2 of GMA. The experiments were carried out according to the procedure described in Subsection 2.5 and the results are represented in Figs. 2-4 and Table 2. 


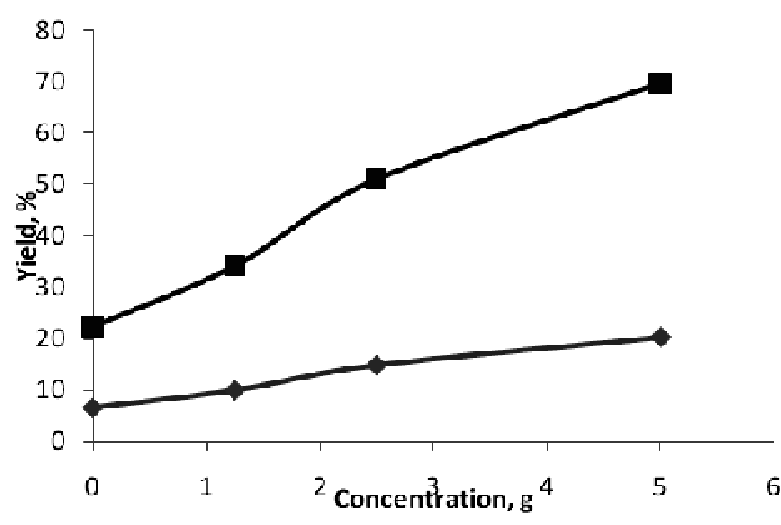

Fig. 2. The effect of PO amount on CIRE yield relative to the initial mixture (1) and resin-formed components (2) at $393 \mathrm{~K}$ and reaction time of $6 \mathrm{~h}$. PO amount $(50 \%$ toluene solution) was calculated relative to 54.85 mass parts of the initial mixture

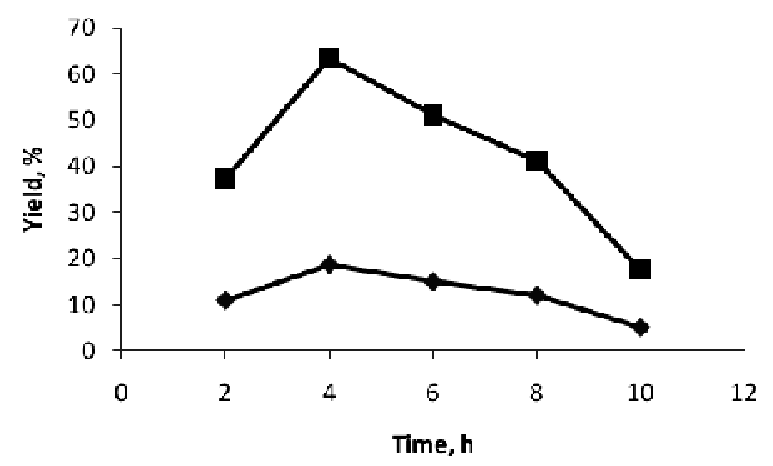

Fig. 3. The effect of process time on CIRE yield relative to the initial mixture (1) and resin-formed components (2) at $393 \mathrm{~K}$. PO amount (50\% toluene solution) is 2.5 mass parts relative to 54.85 mass parts of the initial mixture

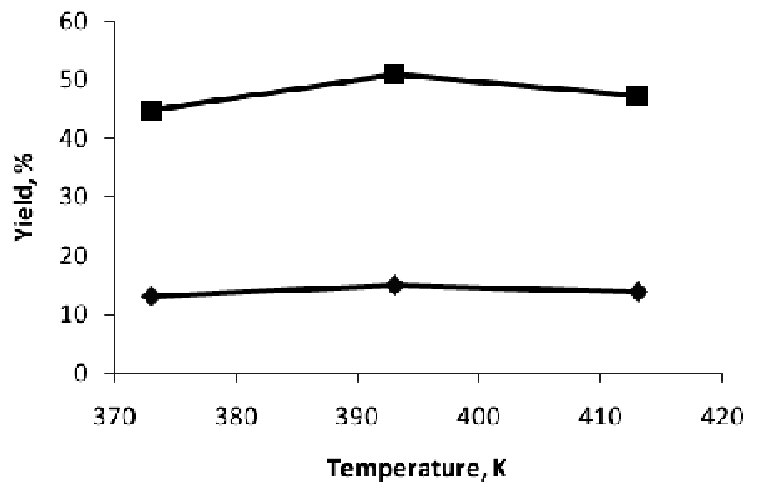

Fig. 4. The effect of process temperature on CIRE yield relative to the initial mixture (1) and resin-formed components

(2) for the reaction time of $6 \mathrm{~h}$. PO amount $(50 \%$ toluene solution) is 2.5 mass parts relative to 54.85 mass parts of the initial mixture
The results from Fig. 2 show that at $393 \mathrm{~K}$ even in the absence of PO the coumarone-indene resins are formed. It means that the monomers in the initial mixture are capable to form resins at this temperature according to the above-mentioned scheme. When using $\mathrm{PO}$ as the initiator, CIRE yield is increased. This fact confirms the assumption that apart from thermal polymerization of the mixture components, the initiation polymerization takes place as well due to the decomposition of PO molecules according to Eqs. (4-9) resulting in formation of free radicals. At the same time PO fragments are introduced into the structure of resulting resin.

Fig. 3 demonstrates the effect of the process time on the CIRE yield. The highest yield is achieved at the process time of 4-6 h (Fig. 3). Further increase in the process time decreases the yield. This fact is explained by destruction processes occurred at high temperature $(393 \mathrm{~K})$ and formation of low-molecular products soluble in petroleum ether and hence incapable of precipitation.

The reaction temperature also affects the CIRE yield (Fig. 4). The increase in temperature from 373 to $393 \mathrm{~K}$ increases the CIRE yield. Further increase to $413 \mathrm{~K}$ decreases the yield of the target product. The reason is deactivation of free radicals at high temperature (vide Eqs. (4-9)), and as a result, the reduction of the share of the reaction leading to the CIRE formation.

The values of the softening temperature of the synthesized CIRE are given in Table 2.

Thus, the following optimal conditions for CIRE synthesis are proposed: the reaction temperature $393 \mathrm{~K}$, reaction time $6 \mathrm{~h}$ and $\mathrm{PO}$ amount (50\% toluene solution) 2.5 mass parts relative to 54.85 mass parts of the initial mixture based on LFCT.

Coumarone-indene resin with epoxy groups (CIRE-3) synthesized under optimal conditions is characterized by the yield of 14.9 and $51.1 \%$ relative to the initial mixture and resin-formed compounds, respectively; softening temperature of $336 \mathrm{~K}$; molecular weight of $1400 \mathrm{~g} / \mathrm{mol}$ and epoxy number of $2.3 \%$.

Next we studied the effect of components ratio on the CIRE yield and the softening temperature using the fraction 423-463 K (ICF) distilled off LFCT (Table 3).

The lowest yields of the finished resin (Table 3) were found for the resin CIRE-12 synthesized in the absence of GMA in the initial mixture. At the same time the simultaneous increase in GMA amount and decrease in styrene amount increases resin yield indicating the essential influence of GMA. We cannot compare softening temperatures of the products which were synthesized using LFCT and ICF because the latter ones were viscous compounds. 
Table 2

Softening temperatures of the synthesized CIRE

\begin{tabular}{|c|c|c|c|c|}
\hline \multicolumn{3}{|c|}{ Synthesis conditions } & \multirow{2}{*}{ CIRE symbol } & \multirow{2}{*}{ Softening temperature, K } \\
\hline Temperature, $\mathrm{K}$ & Time, $\mathrm{h}$ & PO amount, mass parts & & 349 \\
\hline 393 & 6 & 0 & CIRE-1 & 337 \\
\hline 393 & 6 & 1.25 & CIRE-2 & 336 \\
\hline 393 & 6 & 2.50 & CIRE-3 & 376 \\
\hline 393 & 6 & 5.00 & CIRE-4 & 308 \\
\hline 393 & 2 & 2.50 & CIRE-5 & 325 \\
\hline 393 & 4 & 2.50 & CIRE-6 & 315 \\
\hline 393 & 8 & 2.50 & CIRE-7 & - \\
\hline 393 & 10 & 2.50 & CIRE-8 & 325 \\
\hline 373 & 6 & 2.50 & CIRE-9 & 335 \\
\hline 413 & 6 & 2.50 & CIRE-10 & \\
\hline
\end{tabular}
solution.

Notes: The initial mixture consists of (mass parts): LFCT 45.2, styrene 5.45 and GMA 4.2. PO is used as $50 \%$ toluene

Table 3

\section{Characteristics of CIRE based on ICF}

\begin{tabular}{|c|c|c|c|c|c|c|c|}
\hline \multicolumn{3}{|c|}{$\begin{array}{c}\text { Composition of the initial mixture, } \\
\text { mass parts }\end{array}$} & \multicolumn{5}{c|}{ CIRE characteristics } \\
\hline ICF & Styrene & GMA & PO & $\begin{array}{c}\text { CIRE } \\
\text { symbol }\end{array}$ & $\begin{array}{c}\text { Yield relative to the } \\
\text { initial mixture, \% }\end{array}$ & $\begin{array}{c}\text { Yield relative to the resin- } \\
\text { formed compounds, \% }\end{array}$ & $\begin{array}{c}\text { Softening } \\
\text { temperature, } \mathrm{K}\end{array}$ \\
\hline 45.2 & 5.45 & 4.20 & 2.5 & CIRE-11 & 18.30 & 37.60 & $\begin{array}{c}\text { viscous } \\
\text { compound }\end{array}$ \\
\hline 45.2 & 9.09 & - & 2.5 & CIRE-12 & 6.07 & 12.30 & $\begin{array}{c}\text { viscous } \\
\text { compound }\end{array}$ \\
\hline 45.2 & 7.27 & 2.08 & 2.5 & CIRE-13 & 10.30 & 20.90 & $\begin{array}{c}\text { viscous } \\
\text { compound }\end{array}$ \\
\hline 45.2 & 3.64 & 6.25 & 2.5 & CIRE-14 & 19.40 & 40.00 & $\begin{array}{c}\text { viscous } \\
\text { compound }\end{array}$ \\
\hline
\end{tabular}

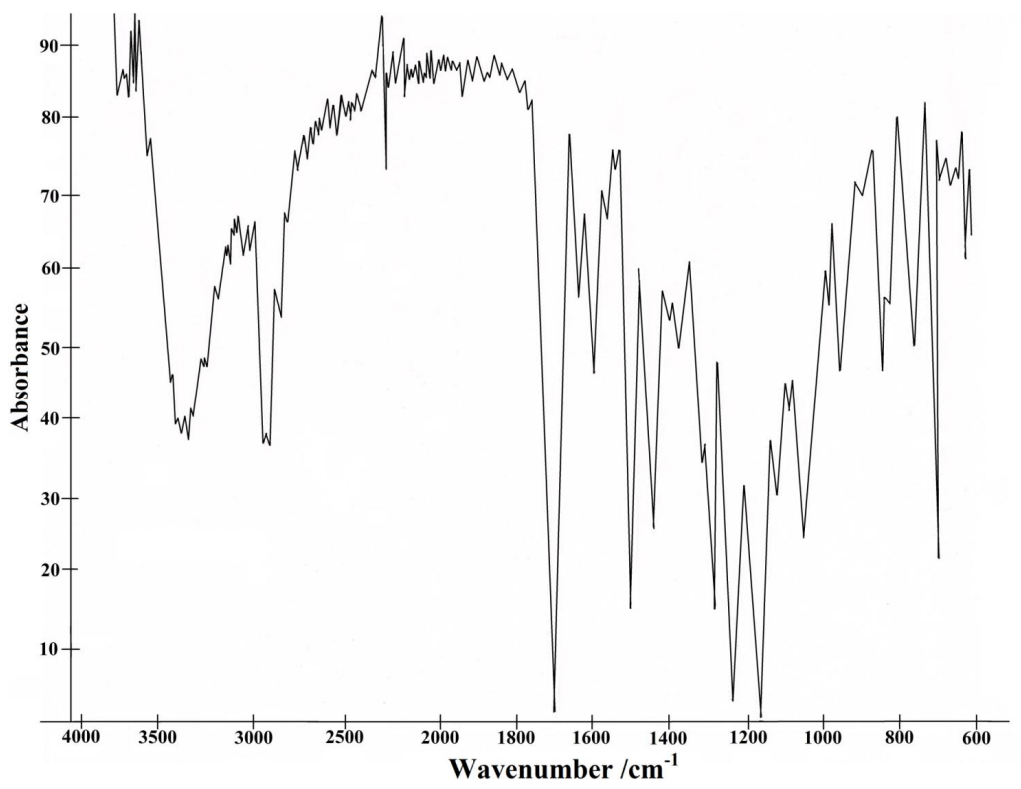

Fig. 5. IR-spectrum of CIRE-11 


\subsubsection{Spectroscopic Investigations}

IR-spectroscopy was used to confirm the structure of the synthesized resins. The investigations were carried out according to the procedure described in Subsection 2.4. The spectra were recorded for CIRE-11. The results are represented in Fig. 5.

The presence of epoxy groups in the synthesized resin is confirmed by the absorption band at $944 \mathrm{~cm}^{-1}$. The presence of $\mathrm{OH}$ group in coumarone-indene resin formed due to the initiation of unsaturated compounds in the initial mixture by PO is confirmed by the absorption band at $3368 \mathrm{~cm}^{-1}$. Moreover, the $\mathrm{H}_{3} \mathrm{C}-\mathrm{C}-\mathrm{CH}_{3}$ fragment in the resin structure is confirmed by gel-dimethyl vibrations at 1384 and $1356 \mathrm{~cm}^{-1}$; the etheric bond - at $1172 \mathrm{~cm}^{-1}$; benzene rings - at 1600 and $1512 \mathrm{~cm}^{-1}$. The entering of GMA molecule with the esteric bond into the resin structure is confirmed by absorption bands at 1720, 1244 and $1046 \mathrm{~cm}^{-1}$.

Thus, the investigation results confirm the presence of epoxy groups in the CIRE structure. We also observe
PO fragments in the spectra. On the other hand, taking into account Eq. (4) we may assert that epoxy groups in CIRE structure are introduced by the fragments of an initiator. The initial reaction mixture contains GMA which enters the resin structure during copolymerization and thus introduces epoxy groups as well.

To establish the role of the initiator and GMA in the process of resin formation we carried out the experiments with the mixture based on ICF. The composition of the mixture is given in Table 4 .

One can see from Table 4 that the reaction mixture used for the CIRE-15 synthesis does not contain GMA. PO with epoxy groups in its composition is the initiator. In the case of CIRE-16 the reaction mixture contains GMA but the initiator is AMP without epoxy groups. According to the obtained results we assume that $\mathrm{PO}$ provides the presence of epoxy group in the structure of CIRE-15. As for CIRE-16, the epoxy groups may occur due to the introduction of GMA fragments into the resin structure.

To confirm the above-mentioned assumption we carried out ${ }^{1} \mathrm{H}$ NMR spectroscopic investigations with the synthesized resins CIRE-15 and CIRE-16. The results are represented in Figs. 6 and 7.

Table 4

\section{Composition and synthesis conditions of the reaction mixture and CIRE characteristics}

\begin{tabular}{|c|c|c|c|c|c|c|c|c|c|}
\hline \multicolumn{5}{|c|}{ Composition of the initial mixture, mass parts } & \multicolumn{2}{|c|}{$\begin{array}{c}\text { Copolymerization } \\
\text { conditions }\end{array}$} & \multirow[t]{2}{*}{$\begin{array}{c}\text { CIRE } \\
\text { symbol }\end{array}$} & \multicolumn{2}{|c|}{$\begin{array}{l}\text { Yield relative to the } \\
\text { initial mixture }\end{array}$} \\
\hline ICF & Styrene & GMA & PO & AMP & $\begin{array}{c}\text { Temperature, } \\
\text { K }\end{array}$ & Time, $\mathrm{h}$ & & $\mathrm{g}$ & $\%$ \\
\hline 118 & 47 & - & 7.9 & - & 403 & 7 & CIRE-15 & 36.6 & 22.2 \\
\hline 45 & 15 & 5 & - & 0.6 & 353 & 8 & CIRE-16 & 19.5 & 29.7 \\
\hline
\end{tabular}

Note: $\mathrm{PO}$ is used as $50 \%$ solution in toluene; $\mathrm{AMP}-2,2$-azobis(2-methylpropionitrile) as $0.2 \mathrm{M}$ solution in toluene

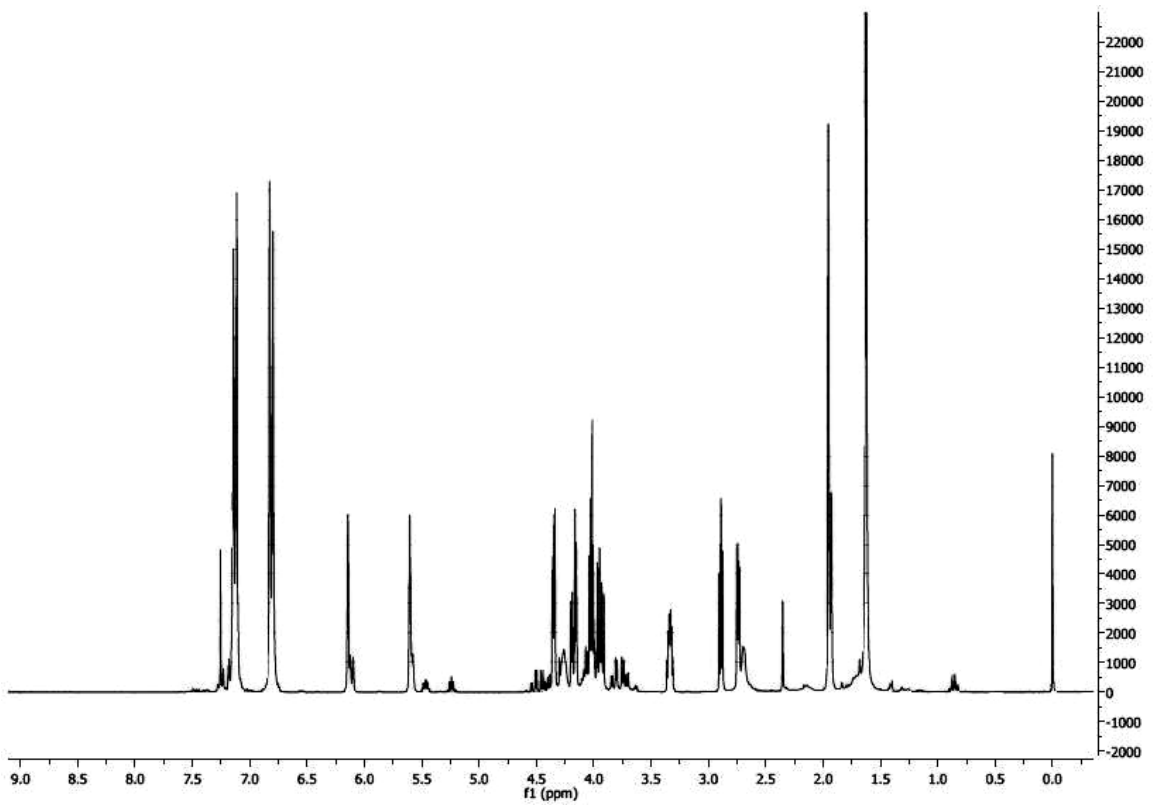

Fig. 6. H NMR spectra of CIRE-15 


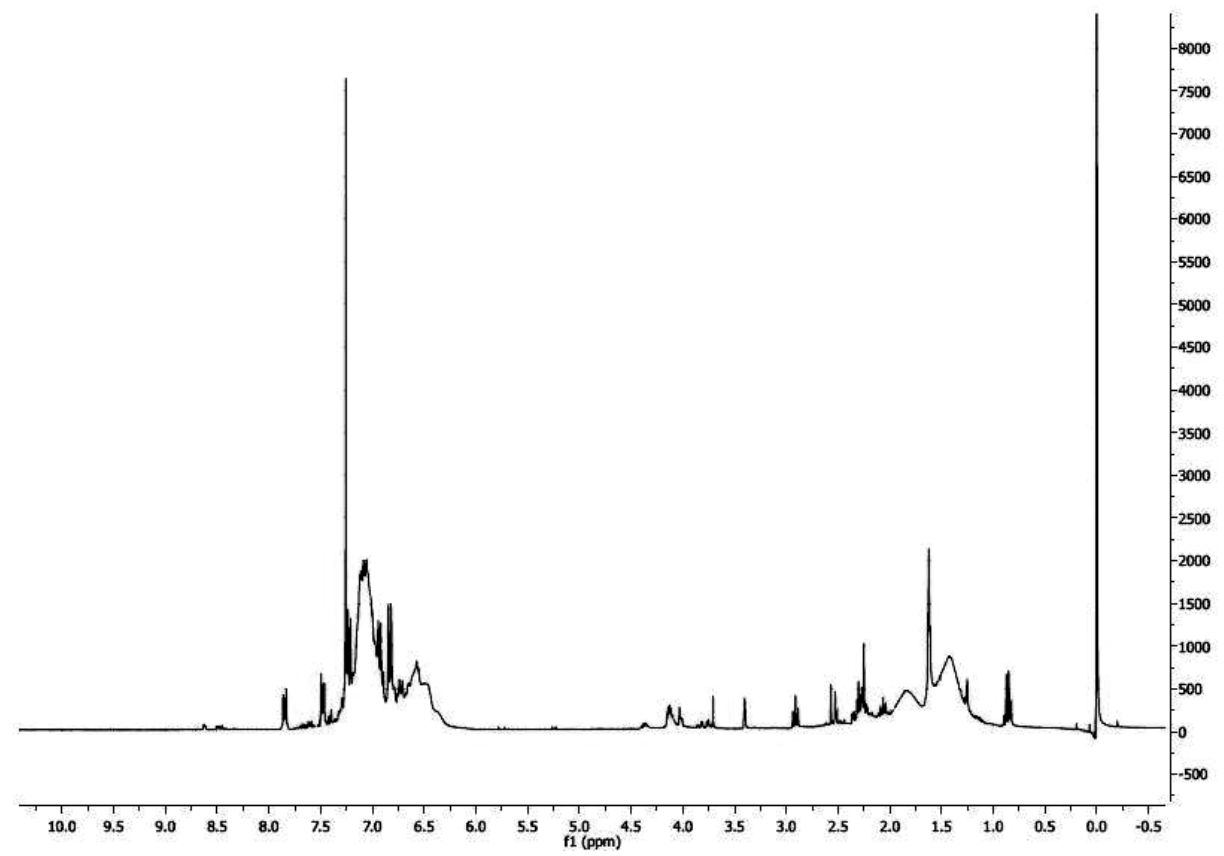

Fig. 7. H NMR spectra of CIRE-16

The analysis of CIRE-15 which was synthesized using PO as the initiator in the absence of GMA shows in the spectrum (Fig. 6) the chemical shifts of protons at 2.25-2.30 ppm corresponding to $\nabla^{\mathrm{CH}}$ group and shifts at 2.50-2.90 ppm typical of ${ }_{2}^{\mathrm{H}_{2} \mathrm{C}-}$ group. These shifts indicate the presence of free epoxy groups in the molecule of CIRE-15. At the same time we observe chemical shifts at $\quad 1.76$ and $1.25-1.30 \mathrm{ppm}$ corresponding to $\mathrm{H}_{3} \mathrm{C}-\underset{\mathrm{C}}{\mid}-\mathrm{CH}_{3}$ and $\left(\mathrm{CH}_{3}\right)_{3} \mathrm{C}-$ groups, respectively. This fact confirms the participation of $\mathrm{H}_{2} \mathrm{C}-\mathrm{CH}-\mathrm{CH}_{2}-\mathrm{R}-\mathrm{CH}_{2}-\underset{\mathrm{OH}}{\mathrm{CH}}-\mathrm{CH}_{2}$ and $\left(\mathrm{CH}_{3}\right)_{3} \mathrm{CO}^{\mathrm{ü}}$ radicals formed due to the $\mathrm{PO}$ decomposition in the formation of CIRE-15. The presence of $-\mathrm{CH}_{2} \mathrm{O}-$ bond introduced into the resin structure is confirmed by the signals at $3.60-4.30 \mathrm{ppm}$; aromatic rings - at 6.80-7.20 ppm. The experimental results show that PO plays a double role in a copolymerization process. On the one hand, it is the source of free radicals which initiate polymerization of unsaturated compounds contained in the initial mixture; on the other hand PO introduces epoxy groups into the resin molecule.

CIRE-16 was obtained using AMP as the initiator; GMA was a carrier of epoxy groups (Table 4). We observe in the spectrum (Fig. 7) no chemical shifts at $1.25-1.30$ and $1.60-1.75 \mathrm{ppm}$, indicating the absence of
$\left(\mathrm{CH}_{3}\right)_{3} \mathrm{C}$ and $\mathrm{H}_{3} \mathrm{C}-\mathrm{C}-\mathrm{CH}_{3}$ fragments, respectively. At the same time the spectrum of CIRE-16 contains the proton signals at 2.30 and $2.40-2.80 \mathrm{ppm}$ corresponding to the protons in $\nabla^{\mathrm{CH}}$ and $\mathrm{H}_{2} \mathrm{C} \bigvee_{\mathrm{O}}^{\mathrm{p}}$ groups, respectively. These signals indicate the presence of free epoxy groups which are introduced into the resin structure due to the entering of GMA molecules. The proton signals at 3.65$4.30 \mathrm{ppm}$ typical of $-\mathrm{CH}_{2} \mathrm{O}-$ group also confirm this fact. The presence of aromatic rings is proved by the proton signals at 6.80-7.20 ppm.

The obtained results specify that when we use PO as the initiator for copolymerization of the mixture consisting of LFCT or ICF, styrene and GMA we obtain CIRE with epoxy groups at the ends of the molecule and in the side branches.

\section{Conclusions}

New coumarone-indene resins with epoxy groups (CIRE) were obtained using the light fraction of coal tar (LFCT) or the fraction with the distillation range of 423$463 \mathrm{~K}$ (ICF), with the addition of styrene and glycidyl methacrylate (GMA), in the presence of monoperoxide derivative of dioxyphenylpropane diglycidyl ether (PO) as the initiator. Thermogravimetric investigations prove the decomposition of peroxy groups in $\mathrm{PO}$ at $393 \mathrm{~K}$. We propose the chemistry of PO decomposition followed by 
the formation of radicals and their deactivation. On the basis of studied effect of the initiator amount, the reaction temperature and time the conditions for CIRE synthesis were determined: the temperature of $393 \mathrm{~K}$, time $6 \mathrm{~h}$ and PO amount 2.5 mass parts as $50 \%$ toluene solution relative to 54.85 mass parts of the initial mixture. The mixture consists of (mass parts): LFCT 45.2; styrene 5.45; GMA 4.2. CIRE obtained under optimal conditions has the following characteristics: the yield of $14.9 \%$ relative to the initial mixture, the yield of $51.1 \%$ relative to the resin-formed components, softening temperature of $336 \mathrm{~K}$, epoxy number of $2.3 \%$ and molecular weight of $1400 \mathrm{~g} / \mathrm{mol}$. The presence of epoxy groups in the synthesized resins is confirmed by IR-spectroscopy (absorption band at $944 \mathrm{~cm}^{-1}$ ). ${ }^{1} \mathrm{H}$ NMR spectroscopy demonstrates that the synthesized resins have epoxy groups at the ends of oligomeric chain and side branches.

\section{References}

[1] Hetmanchuk Yu., Bratychak M.: Khimiya ta Technologiya Polimeriv. Beskyd-Bit, Lviv 2006.

[2] Bratychak M., Hetmanchuk Yu.: Khimichna Technologiya Syntezu Vysokomolekuliarnykh Spoluk. Vyd-vo NULP, Lviv 2009. [3] Bratychak M., Gagin M., Shyshchak O., Waclawek W.: Chemia i Inzyneria Ekologiczna, 2004, 11, 15.

[4] Bratychak M., Gagin M., Shyshchak O., Brostow W.: Chemia i Inzyneria Ekologiczna, 2004, 11, 21.

[5] Gagin M., Bratychak M., Shyshchak O., Waclawek W.: Chemia i Inzyneria Ekologiczna, 2004, 11, 27.

[6] Skibitskiy V., Grynyshyn O., Bratychak M., Brostow W.:

Chemia i Inzyneria Ekologiczna, 2004, 11, 41.

[7] Bratychak M., Romashko I., Shyshchak O., Waclawek W.: Ecolog. Chem. Eng., 2006, 13, 7.

[8] Bratychak M., Shyshchak O., Romashko I., Waclawek W.: Ecolog. Chem. Eng., 2006, 13, 17.

[9] Bratychak M., Romashko I., Shyshchak O. et al.: Ecolog. Chem. Eng., 2007, 14, 245.

[10] Bratychak M., Brostow W., Pietkiewicz D., Topilnytskiy P.: Chem. Chem. Technol., 2007, 1, 155.

[11] Bratychak M., Grynyshyn O., Astakhova O. et al.: Ecolog. Chem. Eng., 2008, 15, 387.

[12] Bratychak M., Shust O., Chervinskyy T. et al.: Ecolog. Chem. Eng., 2011, 18, 49.

[13] Chervinskyy T., Bratychak M., Gagin M., Waclawek W.: Chemia i Inzyneria Ekologiczna, 2004, 11, 1225.

[14] Bratychak M., Grynyshyn O., Shyshchak O. et al.: Ecolog. Chem. Eng., 2007, 14, 225.

[15] Grynyshyn O., Bratychak M., Krynytskiy V., Donchak V.: Chem. Chem. Technol., 2008, 2, 47.

[16] Bratychak M., Grynyshyn O., Astakhova O. et al.: Ecolog. Chem. Eng., 2010, 17, 309.
[17] Tiwari H., Sharma R., Kumar R. et al.: Coke Chem., 2014, 57, 477. https://doi.org/10.3103/S1068364X14120072.

[18] Pyshyev S., Gunka V., Grytsenko Y., Bratychak M.: Chem. Chem. Technol., 2016, 10, 631.

https://doi.org/10.23939/chcht10.04si.631

[19] Bratychak M., Astakhova O., Shyshchak O. et al.: Chem.

Chem. Technol., 2017, 11, 509.

https://doi.org/10.23939/chcht11.04.509

[20] https://www.chemicalbook.com/ChemicalProductProperty_ EN_CB3415111.htm.

[21] Bratychak M., Chervinskyy T., Gagin M. et al.: Ukr. Khim. Zh., 2005, 71, 50.

[22] Braun D., Cherdron H., Rehahn M. et al.: Polymer Synthesis: Theory and Practice: Fundamentals, Methods, Experiments, $5^{\text {th }}$ edn. Springer-Verlag, Berlin Heidelberg 2013.

https:/doi.org/10.1007/978-3-642-28980-4_1

[23] ASTM- D36/D36M - 14e1. Standard Test Method for

Softening Point of Bitumen (Ring-and-Ball Apparatus).

https://www.astm.org/Standards/D36.htm

[24] Wilson G., Henderson J., Caruso M. et al.: J. Polym. Sci. A, 2010, 48, 2698. https://doi.org/10.1002/pola.24053

\section{Acknowledgments}

The work was carried out under financial support of the grant DB/Bitum No. 0117 U 004451 of the Ministry of Education and Science of Ukraine.

Received: September 12, 2017 / Revised: October 20, 2017 / Accepted: November 15, 2017

\section{ОДЕРЖАННЯ ІНДЕН-КУМАРОНОВИХ СМОЛ З ЛЕГКОЇ ФРАКЦІЇ КАМ‘ЯНО-ВУГІЛЬНОЇ СМОЛИ \\ 2. ІНДЕН-КУМАРОНОВІ СМОЛИ З ЕПОКСИДНИМИ ГРУПАМИ}

Анотація. 3 використанням легкої фракиії кам'яновугільної смоли та отриманої на ї̈ основі фракції, щчо википає за температур 423-463 K з додаванням стиролу $i$ глічидилметакрилату розроблений метод одержання інден-кумаронових смол з епоксидними групами (IКСЕ). IКСЕ отримані за радикальною коолігомеризачією з використанням як інічіатор монопероксидної похідної диглічидилового етеру діоксидифенілпропану (ПО). Вивчена терміна стабільність ПО. Встановлено вплив кількості ініціатора, температури та тривалості реакиії на вихід та температуру розм'якшення IKCE. Структура синтезованих IКСЕ підтверджена IЧ- та ${ }^{1}$ Н ЯМР спектроскопічними дослідженнями.

Ключові слова: інден-кумаронова смола, кам'яновугільна смола, стирол, малеїновий ангідрид, глічидилметакрилат, пероксид, термоліз, IЧ-спектроскопія, ${ }^{l} \mathrm{H}$ ЯМРспектроскопія. 